\title{
The Apocalyptic Chronotope in "Farewell to the Master" and The Day the Earth Stood Still
}

\author{
“Efendiye Elveda” ve Dünyanın Durduğu Gün'de Kıyamet Kronotopu
}

\section{Züleyha ÇETINER ÖKTEM *}

\begin{abstract}
Mythic and religious narratives that envision the end of the world position the apocalypse in a futuristic time where certain events would sequentially occur finally building up to the inevitable end. Speculative fiction that depicts near-apocalypses do not however, prefer unconceivable futures but favour the current time of the narrative, depicting them as events happening now. Operating within the apocalyptic chronotope, science fiction bonds present day concerns with possible catastrophes. One such narrative is Harry Bates' short story "Farewell to the Master" (1940) which also generated two film adaptations entitled The Day the Earth Stood Still (1951, 2008). While Bates' short story relates how humanity is prone to act imprudently during a relatively peaceful period, the 1951 film turns to that of the Cold War and its repercussions, and the 2008 remake of The Day the Earth Stood Still centres around the theme of nature. As environmental concerns dominate our era the 2008 film reflects humanity's evergrowing consumption and destruction of its natural surroundings. As the source text and its adaptations provide possible apocalyptic visions or scenarios adjusted to their respective audiences, this essay analyses these narratives through the apocalyptic chronotope, exploring and building on Bakhtin's theory. In doing so, this essay attempts to discern the ways in which adapted near apocalyptic scenarios shift and change to accommodate contemporary concerns within a temporal and spatial framework.
\end{abstract}

Keywords: Science Fiction, Adaptation, Near Apocalyptic Narratives, Bakhtin, Apocalyptic Chronotope

Öz: Dünyanın sonunu hayal eden mitsel ve dinsel metinler genelde kıyameti sırasıyla gerçekleşecek olan alametlerin sonunda, gelecekte bir zamana yerleştirir. Olası kıyametleri betimleyen spekülatif kurgu ise tahmin edilemeyen bir gelecekte değil, metnin şimdiki zamanında gerçekleşen bir olay olarak gösterir kıyameti. Bilim kurgu metinleri, kıyamet kronotopunun içerisinde işleyerek, güncel sorunlarla muhtemel afetleri birbirine bağlar. Buna örnek olabilecek metinlerden birisi ise Harry Bates'in "Efendiye Elveda" (1940) isimli kısa hikayesidir. Bu kaynak metin ayrıca Dünyanın Durduğu Gün $(1951,2008)$ adında iki film uyarlamasına da neden olmuştur. Bates'in kısa hikayesi görece barışçıl bir dönemde insanlığın nasıl öngörüsüz davranabileceğine değinirken, 1951 filmi Soğuk Savaşa ve doğurabileceği sonuçlara odaklanır. Dünyanın Durduğu Gün'ün 2008 yeniden yapımı ise merkezine doğa temasını alır: çevresel kaygılar dönemimize hükmettiğinden, bu film insanlığın doğal çevresini durmadan tüketmesi ve yok etmesini yansıtır. Kaynak metin ve uyarlamaları olası kıyamet görülerini veya senaryolarını dönemin seyircisine uyarlayarak sunduğundan, bu makale bahsi geçen metinleri Bakhtin'in kronotop teorisinden beslenip üzerine yapılandırarak kıyamet kronotopu aracılığıyla incelemeyi amaçlamaktadır. Böylelikle, bu makale uyarlanmış olası kıyamet senaryolarının güncel kaygıları barındırabilmek için zamansal ve uzamsal çerçevede nasıl değişime uğrayıp şekillendiğini irdeleyecektir.

Anahtar sözcükler: Bilim Kurgu, Uyarlama, Olası Kıyamet Metinleri, Bakhtin, Kıyamet Kronotopu

\footnotetext{
Dr., Ege University, Faculty of Letters, Dept. of English Language and Literature, İzmir. zcoktem@gmail.com, https://orcid.org/0000-0001-7401-0437

A shorter version of this article was presented at the Symposium of American Studies (Dokuz Eylül University, İzmir, 27-29 April 2016).
} 
Look well, for before you stand stark symbols of the achievement, mystery, and frailty of the human race.

—Harry Bates, "Farewell to the Master"

\section{Introduction: Apocalypse Now?}

In his seminal work The Sense of an Ending Frank Kermode writes that "Apocalypse depends on a concord of imaginatively recorded past and imaginatively predicted future, achieved on behalf of us, who remain 'in the middest'. Its predictions," he says, "though figurative, can be taken literally, and as the future moves in on us we may expect it to conform with the figures" $(2000,8)$. The significance of Kermode's work, according to David Seed "was its central insight that apocalypse was a narrative, one of the fictions which we employ to make sense of our present" (2000, 11). Thus each epoch, continuously rewriting its own apocalyptic narratives, envisions possible endings that mirror present day issues and concerns. In this sense, apocalyptic narratives reflect recurrent "patterns of anxiety" (Kermode 2000, 96) that implore us to understand the present. If "[science fiction] films reflect world-wide anxieties, and they serve to allay them" (Sontag 1965, 42), then it becomes possible to trace how these anxieties are reflected and resolved from a temporal and spatial point of view in near apocalyptic science fiction narratives that stem from the same source.

The near apocalypse depicted in Harry Bates' short story "Farewell to the Master", first published in the 1940 October issue of Astounding Science Fiction, forms the backbone of two movies, consecutively entitled, The Day the Earth Stood Still. The first film, directed by Robert Wise in 1951, centres on the concept of war and the remake released in 2008, directed by Scott Derrickson, is wound around environmental concerns. All three narratives provide possible apocalyptic visions or scenarios where humanity, as a race, is prone to self-destruction yet at the same time has redeemable qualities. Inasmuch as their focal point may differ, these narratives offer apocalyptic visions that serve as warning stories. Although there is a sense of impending doom and the possibility that the world as we know it may cease to exist, it never actually does. The mere idea that "the end" is near serves as the sublime element enhanced through multilayered messages embedded in these various representations of apocalyptic narratives which may be seen as futuristic destruction myths based on the current day anxieties that we try to deal with.

Generally serving as warning stories, mythic and biblical narratives that envision the end of the world position the apocalypse in a futuristic time when sequentially occurring signs and events would finally lead to the inevitable end. Speculative fiction that depicts nearapocalypses, however, does not prefer unconceivable futures but favours the current time of the narrative, depicting them as events happening now. At this point, there is a "need to understand what science fiction is reacting against" (James 2003, 219); but perhaps more importantly there is also a need to understand how and why science fiction is reacting. If for Bakhtin the significance of the chronotope lies in "their meaning for narrative" $(1937-38,250)$ then this would shed light on the what, how, and why of near-apocalyptic and apocalyptic events depicted in these narratives.

\section{The Near-Apocalyptic and Apocalyptic Chronotope}

Apocalyptic narratives, specifically in the science fiction genre, generally depict the frailty of the human race during times of crisis and they are concerned with how humanity emerges from disastrous situations, catastrophes, and handles the anxiety arising from these circumstances. Crisis, comments Kermode "is inescapably a central element in our endeavours towards making sense of our world" (2000, 94); and if catastrophe, as Cara Murray attests, "offer[s] a 
new way of conceptualising space and time" $(2010,150)$, then it becomes possible to view these narratives through the lens of what we may call an apocalyptic chronotope. As apocalypse insinuates "an approaching confrontation, cataclysmic event, or transformation of epochal proportion, about which a select few have forewarning so they can make appropriate preparations" (Berlet 2000, 45), then the human subject along with spatial and temporal elements of apocalyptic narratives take on new meanings. "What marks the necessary presence of a human subject," writes Holquist $(1990,152)$, "is the assumption that time and space are never merely temporal or spatial, but axiological as well". Thus a chronotope not only merges the concepts of time and space but also the values attached to each, insisting on their simultaneity and inseparability.

Chronotopes, for Bakhtin (1937-38, 250), "are the organizing centers for the fundamental narrative events of the novel. The chronotope is the place where the knots of narrative are tied and untied. It can be said without qualification that to them belongs the meaning that shapes narrative". Different genres construct the chronotope in different ways (Bakhtin 1937-38, 97): in science fiction narratives, the genre of destruction, or rather the apocalyptic chronotope, relies on grand narratives depicting the end of the world; it relies on past destruction myths-where the imminent end of the known world is near. It uses these grand narratives to build up its own structure as it plays off these narratives to create a plausible pause in time, a hesitation, an alternative reality made possible. What we have in the end is a reformed version of an apocalyptic vision, a renewed revelation of sorts. In this sense, the apocalyptic chronotope creates what Bakhtin $(1937-38,201)$ calls a "historical dislocation". There is a break from what was envisioned to what is happening in the "now" of the narrative. In his analysis of biblical texts Vines (2007, 116) suggests that "apocalypse is an essentially 'finalizing' genre: an attempt to fix the axiological position of human activity and then measure it in relation to divine standards of justice. Within the world of the apocalypse there is no room for rebuttal or justification. Invariably, the cosmos is found to be deeply, if not fatally, flawed". The narratives treated here are also similar in this respect; however, they also allow room for redemption.

The apocalyptic moment, the catastrophic image, is chronotopic. The landscape is not simply a setting for the action, but is significant as it poses meaning tied to the action. "Where" the action takes place is as important as "when;" and even more so, as the place creates the unspoken yet felt atmosphere, an image that builds up the story for the setting of the narrative. Hinting at a possible apocalypse (whether it comes to pass or not) hearkens to the mythical and biblical narratives describing the world's end. This apocalyptic chronotope is suspended between these grand narratives and the time/space of the text itself. With this approach in mind, the key points that will be considered under the banner of an apocalyptic chronotope are: the nature of time and space, the nature of place that connects time and space, the determination of action and events, and the depiction or image of the individual in all three narratives. Accordingly, the source text, "Farewell to the Master", analysed in detail below will flesh out the apocalyptic chronotope by focussing on how time and space, action and events, and individuals are depicted. This detailed evaluation, in turn, will allow for a more focussed analysis of both film adaptations The Day the Earth Stood Still $(1951,2008)$.

\section{The Apocalyptic Spectre in the Source Text “Farewell to the Master” (1940)}

Bates' short story, penned in the post Great Depression era, does not really dwell on any specific matter per se but relates how humanity is prone to act imprudently. It still, however, carries with it the shadow of past and present real time events: about a decade after the trauma of WWI, the US experienced the devastation of the Great Depression (1929-1939) and in 1939 Europe was on the verge of WWII; Pearl Harbour (7 December 1941) was yet to come. So, with 
WWI in the rear-view mirror and WWII raging on in a faraway mythical land called Europe, the American imagination was haunted by the past and disquieted towards the future. Relatively in a time of peace, so to speak, Bates' story focusses on the sense of fear and awe inspired by an alien humanoid called Klaatu, deemed to be divine, and a robot named Gnut, believed to be Klaatu's faithful servant. The sense that the world may crumble at any moment through various means, be it human or alien, is the underlying feeling prevalent in the narrative. The mythical/ biblical apocalypses of the past/future are almost here, in the "now" of the narrative, leaving the human characters in suspension as they wait for a possible apocalypse that may or may not occur.

The original narrative follows the story from Cliff Sutherland's perspective, a freelance picture reporter, or a photo-journalist as we would call him today, who is after his "perfect shot". Cliff represents the inquisitive individual, the figure through which the reader is immersed into the narrative. The story begins in retrospect, after all the major action has already been dealt with: according to these sequentially occurring events, a ship has materialised out of nowhere, an eightfoot robot along with the ambassador, Klaatu, has emerged from the ship, only to be slain and later placed in a glass tomb in the centre of the Tidal Basin. Although the text does not mention the connotations attached to the Tidal Basin, we should note here that this is a human-made reservoir located between the Potomac River and the Washington Channel; with the Lincoln Memorial to the northwest and the Washington Monument to the northeast, the Tidal Basin as part of West Potomac Park, represents a place of memorials, a space of remembrance. The physical location is the Washington D.C. area, but perhaps more importantly, the White House being located towards the immediate north of the Tidal Basin implies political and even military concerns as the presence of armed forces is heavily felt during the encounter with the visitors from the unknown.

Relying on past events, we learn that the Smithsonian Institution, a space of accumulation and diffusion of knowledge, has built a new Interplanetary Wing harbouring its newly acquired exhibits: an unidentifiable spaceship and eight-foot robot. These objects having arrived "from the Unknown" (Bates 1940, n.p.) are treated as relics, as specimens that must be preserved and gazed at, but they also serve as reminders of the events that occurred about "three months ago . . . . A little after 5:00 p.m. on September 16th" (Bates 1940, n.p.). Here the time segments of the narrative interjects with what Bakhtin calls the "suddenlys" and "at just that moments" of adventure time $(1937-38,95)$ as "then it happened. On the area just to your right, just as it is now, appeared the time-space traveler. It appeared in the blink of an eye. It did not come down from the sky . . . it just appeared. One moment it was not here, the next it was" (Bates 1940, n.p.). This sudden materialisation of an unknown space vessel was not only conceived as an act of threat spreading panic but it was also perceived as a divine omen hence the growing sense of wonder, excitement, and anticipation among the populace. The passage of time, exactly two days between the ship's landing and the egress of the alien, only enhanced anticipation as the feelings of fear and awe gradually grew.

The connection between events and actions are almost symbiotic, where one is able to determine the other. The sudden appearance of the spaceship and the delayed appearance of its inhabitants as consecutive events inherently lead to a gradual build-up of anticipation of awe and fear as reactions to these events. These reactions, specifically that of fear disguised as caution, however, causes the military to act, to turn "the muzzles of scores of the army's most powerful guns and ray projectors" (Bates 1940, n.p.) towards the still spaceship. Once an opening appears and a human-like being emerges from the ship, the reaction of fear subsides while the sense of awe is augmented: "out stepped a man, godlike in appearance and human in form, closely followed by a giant robot" (Bates 1940, n.p.). The "alien" as it would seem is human in appearance, therefore, the threat of the unknown somewhat subsides. But the 
anticipation that was built around this figure is torn between the acts of fearing and welcoming. Even though Klaatu's appearance "was friendly", "the expression on his face, which radiated kindness, wisdom, the purest nobility", and "[i]n his delicately tinted robe he looked like a benign god" (Bates 1940, n.p.) he was still shot.

As much as Klaatu resembles a benign god, Gnut is also similarly defined as a divine being that complements Klaatu. Where one is believed to be peaceful, the latter is deemed to possibly be wrathful. The manlike appearance of Gnut, his humanised depiction, and the awe/fear inspiring emotions he awakens in the populace may have something to do with how he is also perceived to possess this divine aspect:

[Gnut] stood like the powerful god of the machine of some undreamt-of scientific civilization, on his face a look of sullen, brooding thought. Those who looked at him did not make jests or idle remarks, and those nearest him usually did not speak at all. His strange, internally illuminated red eyes were so set that every observer felt they were fixed on himself alone, and he engendered a feeling that he might at any moment step forward in anger and perform unimaginable deeds (Bates 1940, n.p.).

Gnut's red gaze is given the power of judgment and possible punishment which implies that the human gazer is attempting to relinquish all fault. Given that the benign god-like Klaatu was slain by a mentally unbalanced person who "kept crying that the devil had come to kill everyone on Earth" (Bates 1940, n.p.) — clearly a representation of apocalyptic fear-the looming silent and still body of Gnut remains as a gentle reminder of the sinful act that resulted in Klaatu's death. Furthermore, the manner in which the populace reacts towards Gnut is full of a deep sense of guilt, shame, and fear. Yet, instead of owning up to the guilt and swallowing the shame, humans prefer to act on their fear and in order to eliminate that fear, they conduct even more profane acts upon a body they had previously deemed to be somewhat sacred:

They sent electrical currents of tremendous voltages and amperages through him. They applied terrific heat to all parts of his metal shell. They immersed him for days in gases and acids and strongly corroding solutions, and they have bombarded him with every known kind of ray. You need have no fear of him now. He cannot possibly have retained the ability to function in any way (Bates 1940, n.p.).

Since humanity has already destroyed the master, it has no scruples attempting to destroy the servant. The sheer delusion of a show of technological superiority aimed to demolish a machine of unknown origins is ironic. Government officials, nevertheless, warn the public that although Gnut has been disabled visitors should still show respect. The reason for these words of caution is because the unknown home of Klaatu and Gnut are imagined to be an extremely advanced civilisation which "may send other emissaries to see what happened to them. Whether or not they do, not one of us must be found amiss in our attitude. None of us could very well anticipate what happened, and we all are immeasurably sorry, but we are still in a sense responsible, and must do what we can to avoid possible retaliations" (Bates 1940, n.p.). So the only reason given in the narrative for the show of respect is the possible retaliation of a superior race, the potential occurrence of an apocalypse; and the motivating emotion is, ironically, fear rather than remorse.

After giving the reader the backstory through an audio message, we are brought forward to the present time of the narrative where Cliff, our picture reporter, sneaks into the Interplanetary Wing after closing hours and hides waiting for Gnut to move, which he has not for over three 
months, or at least no one has seen him move since Klaatu's death. This is the night, however, when Gnut does move and we are left with Cliff's impression of the gigantic robot and the fear it inspires: "This was a chilling thing. Did Gnut know he was there? What were the thoughts of the robot? What could be the thoughts of a man-made machine, even so wonderful a one as Gnut?" (Bates 1940, n.p.). The pre-conceived idea that a machine is human-made and that it probably possesses no consciousness is inherently a part of humanity's anthropocentric perspective. It is perhaps this perspective that anticipates an impending doom, intrinsically generating an apocalyptic chronotope. The realisation of the error of this notion that arrives at the end of the narrative, however, causes an immediate shift in Cliff's, thus the reader's, perception which requires a renegotiation of the previously established connotations between space, time, and the individual.

What Cliff witnesses next is even more astounding. Gnut seems to possess the power, or technology, to briefly duplicate a living and breathing body. This may be seen as a form of cloning technology or, from a divine point of view, a form of resurrection or even creation. Yet the re-created beings do not live long. The experiments Gnut carries out instils Cliff with even greater wonder where he is able to somewhat suppress his fear as he questions whether Gnut is capable of human-like qualities. The explanation for how this technology works is that each body makes a characteristic sound and from that characteristic sound one may reconstruct the respective body that belongs to that sound. In an almost Old Testament-like creation, the corporeal body follows after the word. So Gnut constructs an apparatus which enables him to recreate Klaatu, albeit briefly, and before Gnut leaves, the dialogue between him and Cliff further highlights humanity's misconceptions:
"Gnut," he said earnestly, holding carefully the limp body in his arms, "you must do one thing for me. Listen carefully. I want you to tell your master-the master yet to come-that what happened to the first Klaatu was an accident, for which all Earth is immeasurably sorry. Will you do that?"
"I have known it," the robot answered gently.
"But will you promise to tell your master-just those words-as soon as he is arrived?"
"You misunderstand," said Gnut, still gently, and quietly spoke four more words. As Cliff heard them a mist passed over his eyes and his body went numb (Bates 1940, n.p.).

When Cliff recovers, he recalls Gnut's last words, which he never told anyone till the day he died. The words were: "You misunderstand; [...] I am the master" (Bates 1940, n.p., emphasis in the original). The narrative ends on this awe/fear inspiring note. Gnut's human qualities as well as his voice may be nullified in the consecutive film adaptations but his significance remains. With the final phrase "I am the master," the narrative not only evokes a chilling surprise but also inherently questions the human condition reflecting upon pre-conceived perceptions that are at times highly narrow considering our many other advancements as a race.

The chronotopic structuring of the source text confines the ensuing events and actions (past and present) to a limited space. The geographical setting of the narrative is Washington D.C. where references are made to the Tidal Basin and the Smithsonian Institute. These places not only allude to spaces of remembrance but also to preservation and archive. Although the White House is never openly mentioned in the text, the closeness of the Presidential abode lends the narrative deeply-seated political and militaristic connotations. As for time, the narrative fluctuates from present to past to present, moving in and out of these charged spaces. The axiological 
aspects that add another layer of meaning to the chronotope are infused into the text through the perceiving and perceived composite individuals. Through Cliff we are made privy to the "now" and through Klaatu and Gnut to the "then" (and "now") of the narrative. The tension between past and present reaches its peak when the "then" and "now" ceases to refer directly to the events and actions of the text and begins to insinuate mythical and biblical narratives of destruction. This overall atmosphere generates a near-apocalyptic chronotope where the anticipation of apocalypse is there yet the actual event itself is missing.

In the following adaptation and remake of this story, the chronotope of the apocalypse becomes more visible, partly due to Klaatu and the robot's active participation in the events of the narrative and partly because of the overwhelming fear of the world's possible end in real life. In the 1951 adaptation, the emotions generated in the aftermath of the atomic bomb and the ensuing Cold War are consistently layered in the background, while the 2008 remake centres the narrative on how humanity is destroying the environment and consequently killing the earth. These two narratives openly suggest that the possible apocalypse is entirely humanity's fault; hence the need for an alien/divine intervention.

\section{On the Brink of a Possible Apocalypse in The Day the Earth Stood Still (1951)}

The 1951 film turns to the concepts of war and technology, the early Cold War and the Atomic Age to be precise. As the ship flies in, the setting is once again Washington D.C. dubbed "the mighty centre of a mighty nation" (Wise 1951). The political connotations are evidently striking as the sense of panic and fear continuously mount to breaking point, when to shoot first and ask questions later become the order of the day. Once the ship has landed, all tanks, artilleries, machine guns, along with every eye is trained upon the ship. The idea that this is an invading army with unknown origins infuses itself into the populace. It is the "origins unknown" aspect of the flying saucer that generates panic and fear. Similar to the source text, "[t]he irrational fear of the unknown plays a key role in the development of the story" (Skoble 2008, 93). Unlike the original story, however, the arrival of the spaceship is not given in retrospect, but is an event happening in the "now" of the narrative. Once the door opens, Klaatu speaks his first words, telling the gathered crowd of civilians and the surrounding military that they came "in peace and with goodwill" (Wise 1951). Klaatu is, however, immediately shot and wounded, after which Gort (previously Gnut in Bates' story) begins disintegrating weapons and tanks with his energy ray. The world these aliens have flown into is full of tension and suspicion. It is an age where technological advancements are multiplying and harnessing atomic power gives an advantage to the country that wields this power.

The reason why Klaatu is here on Earth is briefly described as concerning the existence of every living creature on Earth, which in the 1950s meant only humans. Although the future of the planet is at stake, it is up to human beings to determine its fate. Klaatu asks to address all the members of the UN, which is denied on the basis that the major players in the political arena distrust one another, covertly referring to the tension between the United States and the Soviet Union. Although "[a]ccounts of 1950s US sf movies typically stress the themes of anticommunism and nuclear anxiety. . . the suggestion that the paranoia suffusing many 1950s sf movies is about communism is as banal as it is difficult to sustain" (Bould 2003, 85-86). The paranoia here, I believe, is primarily based on the many devastations humanity visited upon itself in actual time: Pearl Harbour was ten years ago, Hiroshima and Nagasaki only six. The trauma and suffering these events produced in real time translates into the fear of being annihilated in narrative time. If anything, what these actual events proved was that apocalypse was not something that belonged to an indefinite mythical/biblical future, but was an event that could very well belong to the immediate present. 
Having received unsatisfactory responses from Mr. Harley, the Secretary to the President, Klaatu decides to evaluate Earth and its inhabitants on his own. He escapes from the clutches of the military (an enclosed and monitored space) and leads a very brief civil life (an open and public, social space) where he meets a young widow by the name of Mrs. Benson and her son Bobby. With the introduction of new characters into the narrative sequence-in Bates' short story there was no love interest for Klaatu, nor any connections to a child, these sub-plots were invented solely for the film(s) - Klaatu is able to see the world through the eyes of representatives of the minority class/es. In the source text, the story of Klaatu was succinctly related as a past event; as the plot did not revolve around the actions of Klaatu, the addition of further characters was unnecessary. In this adaptation, however, because the audience encounters Klaatu in the real time of the narrative, his interactions with others allows viewers an insight into his thoughts, emotions, and motives. Therefore, the inclusion of these characters becomes necessary in order to present Klaatu in an axiological context. This also enables us to better define the apocalyptic chronotope. The sequence of having Klaatu arrive in the "now" of the narrative creates a fracture in its temporal linearity. At this specific juncture, the textual world is transported to a biblical time where the earth, but especially Washington D.C., becomes a charged space. Biblical time and regular time seem to be occupying the same space, and this in turn creates grounds for further tension and anxiety.

Being immersed in social time as well as both public and domestic spaces allows Klaatu to figure out humankind. Yet at the same time Klaatu is redefining himself: he stays at a B\&B (a safe and social environment), becomes immersed in the everyday life of humans, and also adopts a human name. Even though the narrative presumably assumes regular time, biblical time is still there in the background specifically through the body of Klaatu. Here, Klaatu quite accidentally becomes Mr. John Carpenter who, as screenwriter Edmund North has commented, was meant to be a subliminal representation of Jesus Christ (cited in Rubin, 1976, 18). Hence, the initials JC and carpentry being Jesus's profession; furthermore, Klaatu is misunderstood throughout and finally executed, but then he is resurrected and he ascends into the night sky. With the biblical metanarrative in the foreground of western thought, the Christian parallels seem obvious. Interjecting here, I would like to add that the description of Klaatu given in Bates' version where he is likened to a god-like figure might also have been one of the reasons why decades later critics and commentators unconsciously considered Klaatu as a Christ-figure in Wise's The Day the Earth Stood Still. Krin Gabbard, for example, applauds Wise's movie for taking " $a$ stand against the anti-Communist hysteria of the McCarthy era" and asserts that "the film is all the more remarkable for its use of the Christ myth to make its point" (1982, 150). Robert Torry looks at Wise's film from its historical perspective while adding that it "exploits the religious resonances of a visit from above by a wise, powerful, and concerned alien intelligence" $(1991,12)$. Cyndy Hendershot considers both Klaatu and the scientist Barnhardt to be "messianic figures" $(1997,31)$ where "Wise's film seems to accept the scientist as a savior figure, extolling Klaatu as Christ-like and Barnhardt as a faithful disciple” (1997, 36). And Anton Kozlovic provides a detailed template wherein he identifies twenty-five characteristics of the cinematic Christ-figure most of which are applicable to Wise's film (2004, n.p.). On the other hand, Douglas Cowen argues that although Wise's film has since the late 1970's consistently been interpreted as a Christian allegory, there are other ways we might read the text, pointing out that "Klaatu is a Christ-figure not because he is or because Robert Wise intended him to be, but because the cultural dominance of Christianity has intruded into the interpretive process to make him so" (2009, n.p.). On another note, Dennis Barone has written that "Klaatu resembles the devil more than he resembles Christ, and he leaves us not safe in a new and secure peace, but locked into a global strait jacket” (1996, 202). Considering all the 
previous criticism that viewed Wise's The Day the Earth Stood Still as a Christian allegory, Aeon Skoble finds "this interpretation implausible, first because Klaatu's message is not that we must all love one another-it's $O K$ if we don't, actually, as long as we don't threaten others-and second because Jesus didn't threaten to have his robot friend blow up the planet if we didn't listen" (2008, 92). According to Joshua Pardon, Wise's movie attempted to communicate a variety of messages to the American film audience of 1951:

a warning about the societal costs of atomic technology, a Christian allegory in the pacifist tradition, a meditation on humanity's potential to transcend its history of barbarism and mistrust by embracing technology, an early attempt at criticizing the mass media, a disturbingly ambiguous commentary on militarism and fascism, and a left-wing polemic against the twin evils of McCarthyist paranoia and the nascent, Cold War-fueled national-security state $(2008,142)$.

Despite the various interpretations of Wise's movie, and the differing messages the film seems to have for its varying audiences, the underlying emotion of anxiety born out of the possibility of annihilation is at its core.

Towards the end of the narrative, we are made privy to the knowledge that a distant planetary federation has sent Klaatu to earth on a diplomatic mission to urge humanity to cease atom-bomb testing that would possibly result not only in a global but also a universal catastrophe. And it is this danger we pose to the rest of the universe that merits a visit from one of their emissaries. Klaatu's message is quite clear in that humanity may continue to act as an autonomous entity as long as it does not threaten other life forms across the vast universe. Ironically, Klaatu "has come in the name of cosmic peace and is the victim of attack and abuse, hypocrisy and fear, misunderstanding and hostility. The leaders of nations across the globe have put petty rivalries before world harmony and military authorities have conspired to undermine his mission," (Lambourne et al. 1990, 72); furthermore, "[o]nly the community of scientists, along with the representations of innocence (a child) and common sense (a woman), have shown appreciation for the urgency and merit of Klaatu's case. So it is with a tone of regret, tinged with ill-feeling, that he takes his leave," (Lambourne et al. 1990, 72) with his ominous message and ensuing ultimatum: "It is no concern of ours how you run your own planet, but if you threaten to extend your violence, this Earth of yours will be reduced to a burned-out cinder. Your choice is simple: join us and live in peace, or pursue your present course and face obliteration. We shall be waiting for your answer. The decision rests with you" (Wise 1951). Here, Klaatu comes across as an agent of destruction reminiscent of the wrathful God of the Old Testament with the threat of fire and brimstone looming over humankind.

This ultimatum does not make its way into the 2008 remake, nor do phrases such as "this Earth of yours" or "your decision". Quite the contrary, the decision has already been made; humanity has been judged and found guilty of the crimes committed against the planet. The story now shifts in perspective, from an anthropocentric view to an ecocritical, object-oriented point of view that dethrones humanity as the supreme ruler of Earth. While Wise's movie "celebrates the rational and presents irrational emotions as simply negative: they are the cause of selfishness, greed, and fear, and must be repressed or transcended" (Jancovich \& Johnston 2011, 74), Derrickson's version accentuates emotion over rationality.

\section{Returning from the Apocalyptic Threshold in The Day the Earth Stood Still (2008)}

In the 2008 remake of the film The Day the Earth Stood Still, the theme of war has been replaced with that of nature. As environmental concerns dominate our era the movie reflects 
humanity's ever-growing consumption and the destruction of its natural surroundings. Klaatu has come to save the Earth from the clutches of humanity who has abused it and who is merely one species amongst millions. So the solution is to sacrifice the few for the benefit of the many. Another major difference is the location in which the space vessel lands. This time we are nowhere near the vicinity of Washington D.C., we are in the very heart of Central Park, Manhattan. This inherently shifts the narrative from political matters, to that of environmental concerns as Central Park becomes a symbolic representative of nature. Central Park, moreover, functions as the archetypal Garden of Eden: a garden that will ensure the continuity of all creatures except for humans who have already fallen and thus have been expelled from the biblical garden. Not only the military but also a group of scientists approach this intriguing vessel, a globe-like structure that resembles the very earth itself; almost like a miniature replica. Similar to previous versions of the story, however, once Klaatu emerges from this unusual vessel, he is immediately shot and wounded. An enormous robot (about twenty-eight feet high, much bigger and more advanced than before) appears, disabling everything around when it receives the command "Klaatu barada nikto" to cease its defensive response.

Klaatu's intervention is critical, but it also gives the illusion-as did Wise's version-that the robot is somehow manageable and/or controllable. This robot is later dubbed G.O.R.T. (Genetically Organised Robotic Technology) by the US military with their enthusiasm for acronyms. Once again the robot is rendered voiceless. The only version of the story where the robot is an autonomous being able to interact intelligently with humankind was in Bates' short story. The consecutive versions seem to have gone out of their way to portray an expressionless, soulless, mechanical entity capable of mass destruction on an apocalyptic level. Perhaps because the later manifestations of the robot are so distant from humanity, it evokes a much more fearful response from the audience: it represents a non-negotiable object, an entity that operates beyond human purview. Not that Klaatu operated within it, but due to his close resemblance to humans, Klaatu was at least considered to be a being one could reason with intelligibly.

Nevertheless, in the events that follow Klaatu's mishap, panic and crisis strikes the New York Stock-Exchange, once more shifting the narrative to menial concerns, while fear of a possible alien invasion grips the world. Although we first encounter the global spacecraft in Manhattan, we soon learn that many other smaller versions have landed all over the planet. This also enhances the reality that environmental planetary concerns do not only involve a single country, or a single continent, but involve the whole world: this is a global problem. By shifting the story to encompass the whole Earth and not just the current super-power, we are once again reminded that a dominant anthropocentric world-view must be altered. Perhaps the dialogue between Klaatu and the Secretary of Defence, Regina Jackson, may be more enlightening:

Regina: Why have you come to our planet?

Klaatu: Your planet?

Regina: Yes. This is our planet

Klaatu: No. It is not (Derrickson 2008).

This dialogue openly proclaims that planet earth does not belong to anybody. The underlying message sutured throughout the movie, however, reminds the audience that earth is home to all beings that are able to symbiotically live with it; while those who assert their own will and power over it will be punished, and Klaatu is the enforcer of this punishment.

According to the Secretary of Defence, who happens to be a woman named Regina Jackson, during initial encounters (with a reference to Columbus and the Natives) less advanced civilisations are either exterminated or enslaved. It is this fear that motivates Regina to keep Klaatu, the representative of many civilisations, under wrap, under guard and secluded from the 
rest of humanity. It is with the help of Dr. Helen Benson, that Klaatu is able to escape. And here we come to yet another major role change. Mrs. Helen Benson, a secretary from the 1951 version, has been revamped into Dr. Helen Benson, an astrobiologist at Princeton University and Bobby is now Jacob, Dr. Benson's stepson, a boy of colour. With all of these minute yet significant changes, from the place/s the vessel/s land to the portrayal of dominant women and a child of colour, the 2008 remake of The Day the Earth Stood Still at least attempts to decentre previously privileged powers. We could also argue, however, that this attempt is feeble as swapping out a white male in place of a white woman (i.e. the President's Secretary Mr. Harley in the 1951 adaptation with the Secretary of Defence Regina Jackson in the 2008 remake; also note that the name Regina is Latin for "queen"), or that changing the location from Washington D.C. to New York, hardly destabilises white supremacy. The effort is nevertheless applaudable. But the question we should rather be asking at this point is: how do these changes affect the apocalyptic chronotope, if they do at all? One possible response would be that they signify different sets of values crucial for the apocalyptic chronotope. As established above, the presence of human subjects is necessary, as they lend an axiological perspective to both temporality and spatiality without which the chronotope cannot be plausibly defined. Therefore, each one of these characters represent a value that enables temporal and spatial layering.

The tension between Dr. Helen Benson and Jacob (mother and son) is reminiscent of the attitude Klaatu holds between himself and humanity: seemingly cold at first but gradually building an unbreakable bond where sacrifice of self is favoured for the continuation of the latter. It is Helen's love and sacrificial desire to save Jacob that resonates with Klaatu. The almost robotic and extremely logical Klaatu gradually undergoes a transformation through various human interactions where he is able to comprehend human emotion and understanding. It is Professor Barnhart, Helen Benson and her stepson Jacob that act as agents influencing Klaatu. A biblical reading would see this transformation as reminiscent of the gentle and merciful being of the New Testament rather than the wrathful deity of the Old Testament.

Previously, when asked if Klaatu was a friend to us, he had replied that he was a friend to the earth and that he had come to save the earth. From an anthropocentric view, one could take this to mean humanity; however, as we come to realise, this assumption is far from what Klaatu actually means. He has indeed come to save the earth, but he has come to save it from humanity. The globe-crafts scattered across the Earth, therefore, function as arks collecting as many species as they can, with the exclusion of humans. The reason for the expulsion of humans was explained simply enough through Klaatu's words: "This planet is dying. The human race is killing it” (Derrickson 2008). Back at Fort Monmouth, US Secretary of Defence Regina Jackson and her team are trying to determine the true function of the active spheres:

Granier: They're ordinary invertebrates-they're collecting specimens.

Driscoll: They're not an invasion force. They're stealing life from our planet...

Regina: It's not our planet.

Driscoll: What?

Regina: "It's not our planet." That's what he said to me. He's not stealing life from Earth. He's rescuing it... An ark. [...] It's an ark. So are the other spheres. They're saving as many species as they can. Granier: But if the spheres are the ark, then what comes next is... Regina: ... the Flood. (Derrickson 2008)

The mounting awareness that we are not the sole owners/inhabitants of the planet and that we have been excluded from the Ark drives home the fear of the human race being completely annihilated. If overt references to biblical myths were absent from previous versions, then the 
2008 version does not disappoint as it makes explicit references to the deluge, god, and the imminent apocalypse. A later dialogue in the home of Professor Barnhardt also hints at the possible divine aspect of Klaatu's role. Even though this reference is not very revealing, it nevertheless gives us some idea of Klaatu's function:

Helen: What are you, some kind of God? Is the universe some kind of garden where you cultivate the flowers and pull up the weeds?

Klaatu: Something like that. (Derrickson 2008)

As a possible caretaker, an overseer of Earth, Klaatu explains to Professor Barnhardt that the problem is that humanity itself that lacks the will to change, and that they treat the world as they treat each other: meaning that we are prone to annihilate those around us as well as our surroundings. Yet, Professor Barnhardt, the voice of logic, argued that humanity was on the brink of destruction and that it was only at these crucial moments that the will to change happened, only on the precipice was evolving (evolution) possible. The voice of reason, Dr. Benson had argued that humanity could change; but it was her interaction with Jacob, the voice of innocence, that actually showed Klaatu that there was another side to humanity rather than destruction. Only through Klaatu's self-sacrifice was the earth's imminent destruction negated, giving humanity one last chance at redemption and survival.

In all of these narratives, however, although the main character seems to be Klaatu, would it be possible to posit the robot (Gnut, Gort, or G.O.R.T.) as the linchpin of all three narratives? Can we consider this non-human character as an embodiment of our culminated fear come to life? In the original story, Gnut not only had a voice but also acted as an autonomous being capable of extraordinary feats. With the final admonition that it was the master, we witnessed the fear caused by not being able to recognise a supreme/divine being. In the ensuing versions, the robot gradually becomes a more menacing being: it no longer has a voice and each incarnation instils an amounting sense of fear. The eight-foot robot in the 1951 version was built, given supreme control, and was capable of destruction on a mass scale. At least that is what we are told. It also had a fail-safe instruction "barada nikto" that came with it, just in case things got out of hand. In the 2008 film, we actually witness the twenty-foot robot composed of a vast swarm of insect-like self-replicating nanites annihilate everything it touches. It is no longer a matter of hearsay. We actually witness the destruction of the swarming locust on a biblical scale. Without speech, or any other means of communication, there can be no dialogue, and thus no appeal. If we consider the robotic figure to be the linchpin, then Klaatu is the bridge between it and humankind. Without Klaatu, humanity is left with only an entity that doles out punishment in the form of mass destruction. It seems the greater our apocalyptic anxiety, the more horrific we envision the ultimate other.

\section{Conclusion: Apocalypse Always}

True to its mythical and biblical roots, apocalyptic science fiction centres on the possible annihilation of the human race. These narratives function as cautionary tales that offer insight into the general wrongs of the human condition. The reason why this genre is resilient and captivating is that we need a release from a definite ending. As Barkun $(2013,176)$ writes, " $[a]$ definitive apocalypse-a final calamity from which there is no escape-can be more easily sustained as a fictional conceit than as an authentic future expectation. Even in fiction, however, it appears difficult to believe in an apocalypse from which there is no exit". So, although the apocalyptic narrative presents the ultimate threat, it also allows for possible solutions and a chance for redemption. The possibility of salvation sustains the apocalyptic chronotope in science fiction narratives. This chronotope creates a hesitation in real time as it bridges 
mythical/biblical temporality and spatiality with the current time-space of the narrative.

"From what temporal and spatial point of view does the author [director] look upon the events that he describes?" asks Bakhtin (1937-38, 255). Fusing the emotional reactions to the temporal and spatial perspectives, Bates centres his story in Washington D.C. and relates the alien arrival in retrospect, where otherworldly awe quickly turns into fear. This fear, however, most probably emerged from recent traumatic events: specifically WWI and the Great Depression. Wise stays true to the emotional impact of the narrative and depicts the events as occurring in Washington D.C., however, the temporal view shifts to real historical time where post WWII anxieties are fuelled by fear of the Atomic Age and the Cold War. Derrickson, on the other hand, shifts both temporal and spatial elements to a more contemporary time where the initial place where the events begin to unfold are in Central Park, Manhattan. This version reveals humanity's current anxiety of destroying the earth, thus in a way rewriting our own possible apocalyptic end.

All in all, these three narratives provide possible apocalyptic visions or scenarios where humanity, as a race, is prone to self-destruction yet at the same time has redeemable qualities. These near apocalyptic narratives, as warning stories, enhance the possibility of total annihilation; therefore, reminding humanity to dismiss petty concerns and see the bigger picture. These near apocalyptic stories not only offer an ever-evolving narrative structure that endorse the sublime but also provide a platform where springing from the same seed, the same source, are able to continuously restructure and rearrange themselves to current contemporary audiences. Apocalyptic narratives, then, functioning as modern destruction myths, enable an awareness of current affairs and societal anxieties. As long as we are our worst nightmares, there will always be a need for apocalyptic narratives. 


\section{REFERENCES}

Bakhtin M. M. (1937-38). "Forms of Time and of the Chronotope in the Novel: Notes toward a Historical Poetics”. Ed. Michael Holquist. Trans. C. Emerson \& M. Holquist. The Dialogic Imagination: Four Essays (1981) 84-258. Texas.

Barkun M. (2013). A Culture of Conspiracy: Apocalyptic Visions in Contemporary America. California 2013.

Barone D. (1996). "Klaatu was No Angel: A Historical-Contextual Analysis of the Day the Earth Stood Still”. Studies in the Humanities 23/2 (1996) 202-212.

Bates H. (1940). "Farewell to the Master”. Astounding Science Fiction, October, n.p.

Berlet C. (2000). “Apocalypse”. Ed. R. A. Landes. Encyclopedia of Millenialism and Millenial Movements (2000) 45-52. New York.

Bould M. (2003). "Film and Television”. Eds. E. James \& F. Mendlesohn, The Cambridge Companion to Science Fiction (2003) 79-95. Cambridge.

Cowan D.E. (2009). "Seeing the Saviour in the Stars: Religion, Conformity, and the Day the Earth Stood Still”. Journal of Religion and Popular Culture 21/1 (2009) n.p.

Derrickson S. (Dir.) \& Boardman P.H., Goodman G. \& Stoff E. (Producers). (2008). The Day the Earth Stood Still [Film]. United States: Twentieth Century Fox.

Gabbard K. (1982). "Religious and Political Allegory in Robert Wise's the Day the Earth Stood Still”. Literature/Film Quarterly 10/3 (1982) 150-154.

Hendershot C. (1997). “The Atomic Scientist, Science Fiction Films, and Paranoia: The Day the Earth Stood Still, This Island Earth, and Killers from Space”. Journal of American Culture 20/1 (1997) 31-41.

Holquist M. (1990). Dialogism: Bakhtin and his World. London 1990.

James E. (2003). “Utopias and Anti-Utopias”. Eds. E. James \& F. Mendlesohn, The Cambridge Companion to Science Fiction (2003) 219-229. Cambridge.

Jancovich M. \& Johnston D. (2011). “Film and Television, The 1950s”. Eds. M. Bould, A. M. Butler, A. Roberts \& S. Vint, The Routledge Companion to Science Fiction (2011) 71-79. Oxford.

Kermode F. (2000). The Sense of an Ending: Studies in the Theory of Fiction. Oxford 2000.

Kozlovic A.K. (2004). “The Structural Characteristics of the Cinematic Christ-figure”. Journal of Religion and Popular Culture 8 (2004) n.p.

Lambourne R, Shallis M. \& Shortland M. (1990). Close Encounters? Science and Science Fiction. New York 1990.

Murray C. (2010). “Catastrophe and Development in the Adventure Romance”. English Literature in Transition: 1880-1920 53/2 (2010) 150-69.

Pardon J. (2008). "Revisiting a Science Fiction Classic: Interpreting the Day the Earth Stood Still for Contemporary Film Audiences”. Journal of Popular Film and Television 36/3 (2008) 141-149.

Rubin S. (1976). "Retrospect: The Day the Earth Stood Still”. Cinefantastique 4/4 (1976) 5-22.

Seed D. (2000). “Introduction: Aspects of Apocalypse”. Ed. D. Seed, Imagining Apocalypse: Studies in Cultural Crisis (2000) 1-14. London.

Skoble A.J. (2008). “Technology and Ethics in the Day the Earth Stood Still”. Ed. Steven M. Sanders. The Philosophy of Science Fiction Film (2008) 91-101. Kentucky.

Sontag S. (1965). “The Imagination of Disaster”. Commentary 40 (1965) 42-48.

Torry R. (1991). “Apocalypse Then: Benefits of the Bomb in Fifties Science Fiction Films”. Cinema Journal 31/1 (1991) 7-21.

Vines M.E. (2007). “The Apocalyptic Chronotope”. Ed. R. Boer, Bakhtin and Genre Theory in Biblical Studies (2007) 109-117. Atlanta.

Wise R. (Dir.) \& Blaustein J. (Producer). (1951). The Day the Earth Stood Still [Film]. United States: Twentieth Century Fox. 